\title{
The Popular Fronts and the Civil War in Spain
}

TIM REES

Our desire is that all the organizations of the Popular Front be strengthened. Our desire is that all anti-fascist forces be consolidated, wherever they are to be found. Although I know that this can lead to criticism of our position, of our actions, never, never, can it be said that a single member, not a one, has been attracted to the party by the promise of advancement or the lure of personal gain. ${ }^{\mathrm{I}}$

These words were spoken as part of a rousing closing speech made by Jesús Hernández, a leading figure in the Spanish Communist Party (PCE), at a party plenum held in March 1937 . At the time Spain was nine months into its brutal civil war which raged on until the final defeat of the republican side at the hands of General Franco's Nationalists in April 1939. The plenum was held partly to publicize the growing strength of the communist party but its central theme, echoed by all the speakers present, was to extol support for the Popular Front as an alliance of all the political parties and trade unions that supported the republic. In evoking the idea of the Popular Front, and the language of anti-fascism which accompanied it, the PCE was following policies common to the international communist movement. In the context of the war in Spain, Hernández hammered home the message that cooperation was the key to ultimate victory and that the PCE was providing a selfless example in working toward that common goal, all of which was reflected in the title of his speech: "Everything Within the Popular Front."

This plenum, and another held in November 1937, presented the PCE as not just at the heart of the conflict in Spain but as part of a worldwide struggle being led by the international communist movement against the threat of

I Partido Comunista de España, Todo dentro del Frente Popular (Valencia: Ediciones del Partido Comunista de España, I937). 
fascism. The fact that Franco was actively aided by Germany and Italy added to the sense that the civil war encapsulated all the great ideological and international conflicts that had built up by the late 1930s. As a result, the defense of the democratic republic appeared to offer the chance to strike a blow against the seemingly inexorable advance of far-right and fascist movements. While this feeling was strongly shared among liberals and leftists of all political persuasions, making the commitment to support the republic one of the great international causes of the time, it struck a particular chord with communists. This was symbolized by the dispatch of the famous International Brigades of volunteers from around the world - predominantly but not exclusively communists - organized by the Communist International (Comintern). Their decision to fight in Spain resulted in great part from the prominence given by the Soviet Union and the international communist movement since the mid i93os to the need to counter the spread of fascism. The establishment of virulently anti-democratic and anti-communist regimes in Germany by the Nazis in 1933 and in Austria in 1934 by Engelbert Dollfuss were the shocks that had finally prompted Soviet and communist leaders into action. In particular, a remilitarized and aggressive Germany under Adolf Hitler presented a direct threat to the USSR and his rise to power had involved the destruction of the largest non-Soviet communist party. The lesson that Soviet and communist leaders took was that the USSR and communist parties were too weak by themselves successfully to resist the rise of fascism. Under Stalin the USSR had become internationally isolated, convulsed by the internal changes unleashed by his rule. Meanwhile, the official policy of the Comintern and its member communist parties since I928 had been to promote "Bolshevik-style" revolution around the globe and to reject all ideological and political alternatives, including participation in "bourgeois democracies" such as the Spanish republic created in 1931. Now communist leaders increasingly accepted the need to seek alliances with other powers, particularly the Western democracies, and with other political movements on the liberal-left. Their dilemma, however, was how best to do this in ways that were compatible with the ideological integrity and wider aims of the communist cause. In May 1935 this led to the signing of a mutual assistance pact between the USSR and France in a vain attempt to contain German expansionism. Later in July-August of the same year, the Comintern held its seventh and last world Congress in Moscow to discuss, among other matters, the stance of the international communist movement toward fascism. Decisions taken at that Congress paved the way for communist participation in anti-fascist political alliances with other groups, subsequently 
known as popular fronts, and raised the possibility that they might also become part of democratic governments.

The war in Spain marked the highpoint of this popular front approach and is often cited as a prime example of the shift in this direction that the Comintern had taken at its seventh world Congress. During the conflict, communist propaganda lavishly celebrated the role of the PCE as heroic and lauded it as an example of what could be achieved through anti-fascist unity and adherence to the Popular Front. The achievements of other popular fronts at the time were similarly highlighted. Here the principal achievements came through successful participation in electoral politics. Most notable was the victory in the French National Assembly elections of May 1936 of a Front Populaire alliance of center-left parties. This included the formation of a separate Popular Front committee in colonial Senegal that included local communists and which supported the unsuccessful candidacy of the Senegalese socialist Lamine Guèye in the same elections. Less well known, but as significant in its own right, was the electoral and political left-wing coalition initially formed in Chile in I937. In the congressional elections of that year the Popular Front was narrowly defeated, as was its candidate in the presidential contest that followed shortly afterwards. However, in I938 the candidate of the Popular Front, Pedro Aguirre Cerda of the Radical Party, finally captured the presidency with a small majority.

The association of the popular front concept with these dramatic developments has made it the most famous of the "lines" adopted by the Comintern throughout its existence. Even decades later, official histories, commemorations and memoirs viewed communist involvement in the "good fight" against fascism as a moral example still to be emulated and admired. This favorable propaganda justified the activities of the Comintern and its member parties and provided evidence subsequently of communism's anti-fascist credentials. However, closer examination of popular fronts in Spain and elsewhere suggests that their creation and nature were far from straightforward, and their activities and achievements mixed. In fact, even to talk of a coherent popular front strategy that was orchestrated and consistently applied by the Comintern is misleading. The Seventh Congress of the Comintern produced no such clear and transparent guide to action for its member parties. Instead the popular front idea evolved and changed by choice and circumstance. Nor did communist parties necessarily play a leading role in the formation and direction of the political alliances which took the name of popular front. Likewise, the relatively few popular fronts that were created were often quite different in practice despite their shared 
commitment to the cause of anti-fascism. Wartime Spain, in particular, represented a special situation that produced a unique form of the popular front and of communist involvement in it.

What all the popular fronts did share in common was their ultimate failure, alongside the Soviet policy of alliances with the Western democracies. They were not cohesive alliances and all proved unsustainable in the face of internal political differences and deep dilemmas over policy. The Spanish example, in particular, followed a very distinctive course and demonstrated the limited ability of the communists decisively to influence developments. Despite the optimistic hopes of Hernández and other Spanish party leaders in 1937, the civil war ended ignominiously in internal fighting within the republican side that finally destroyed the Popular Front; the result was a crushing defeat that helped hasten the final end of the Comintern itself. The experiment of "popular frontism" in France had already fallen apart under the weight of internal divisions during 1938, followed by the final dissolution of the Chilean example in early 194I. Their immediate successes tended to be correspondingly short-lived and, at best, they delayed rather than prevented the spread of "fascism."

The Seventh Congress of the Comintern was called at a time of grave uncertainty for the international communist movement and the Soviet Union. The new head of the Comintern, Georgi Dimitrov, had witnessed at first hand the rise of the Nazis and the suppression of the German Communist Party (KPD). In Czechoslovakia and France there were growing calls from factions within their communist parties to abandon the attacks on other organizations as "social fascists" and traitors to the working class previously promoted by the Comintern in favor of greater meaningful cooperation. Within the trade unions, in particular, there were also examples of grassroots joint actions involving communist and socialist activists in order to defend workers' rights and to defend wages and working conditions as the effects of economic depression deepened. Meanwhile, the USSR also faced a corresponding threat from a resurgent Germany to the west and an increasingly threatening Japanese presence to the east. For Stalin and his coterie, concern with the security of the Soviet Union was matched by a preoccupation with the tremendous domestic pressures unleashed by the campaigns for collectivization and forced industrialization. While these fears and uncertainty about the immediate future motivated the decision to call a congress, Dimitrov and other leading figures in the Comintern were also aware that the revolutionary idealism of Bolshevism was at the heart of its appeal. The need to "recognize reality," had therefore to be balanced by the 
continuing affirmation of the fundamental tenets of communist political doctrine and identity.

No dramatic "about turn" in Comintern policy was actually announced at the carefully managed Congress, attended by $5 \mathrm{I} 3$ representatives from sixtyfive communist parties. Rather the Comintern leadership signaled new priorities in response to the threat of fascism while theoretically retaining full support for the central aim of spreading Bolshevik-style revolution around the globe. Most of the themes discussed were indistinguishable from previous congresses: attacks on the leaders of other working-class organizations, particularly socialists, as traitors to the cause of real revolution; vehement rejections of "Trotskyism" and other deviations from Leninist orthodoxy; and belief in the USSR as the homeland of socialism and in the inspirational leadership of Stalin. The most controversial item was André Marty's defense of the recently signed agreement between the USSR and France, which was criticized by some delegates as a capitulation to the capitalist and imperialist powers. Otherwise nothing in the language or terminology used departed from the established political lexicon of communist orthodoxy; instead change was introduced by subtle redefinitions and changes of emphasis. In his report Dimitrov used a definition of fascism previously agreed upon by the Comintern's executive, famously describing it "as the open terrorist dictatorship of the most reactionary, most chauvinistic and most imperialist elements of finance capital." While this made clear that fascism was rooted in capitalist society, it also suggested that it could not be seen as simply a form of bourgeois rule like any other. Instead it posed a violent and immediate threat which required a shift in communist tactics which Dimitrov argued should be based upon the creation of a "united front of the working class" which could lead to the formation of "anti-fascist people's fronts.", The concept of the "united front" was already familiar, and had been used in various forms since the founding of the Comintern in I9I9. It was significant that veteran delegates at the Congress, such as Jules Humbert-Droz, were not permitted to speak for fear that they would point out what was now proposed actually marked a step back to a position that the Comintern had held in the early i920s. The final resolutions of the Congress expressed the new formula as "the creation of a broad anti-fascist popular front on the basis of the proletarian united front." Also included in passing were the possibilities of electoral cooperation with non-working-class political parties and communist

2 Georgi Dimitrov, "The Fascist Offensive and the Tasks of the Communist International in the Struggle of the Working Class Against Fascism," in Georgi Dimitrov, Selected Works, vol. II (Sofia: Sofia Press, 1972). 
involvement in "bourgeois governments," but these steps were only to be agreed on a case-by-case basis. Also discussed were the legitimate use of armed force in the face of fascist violence and the formation of workers' militias for the purposes of defense.

Stalin's lukewarm approval, echoed by loyal communist party leaderships, was a sign of his personal disinterest but also of the general uncertainly about what actually was changing. Though no grandiosely titled "popular front" strategy was, in fact, adopted at the Congress, this did not mean that its practical consequences were actually negligible. Most significant was the endorsement of a less dogmatic and prescriptive approach to political tactics on the part of the Comintern. Giving greater priority to the struggle against fascism helped communist parties to take a more flexible attitude toward their activities. This was further reinforced, at least rhetorically, by a call from Dimitrov for party leaderships to take more responsibility for their own actions and to make decisions based upon a self-assessment of local political conditions. This did not mean that parties had carte blanche to do as they liked, far from it. But it did mean they could explore a greater range of political opportunities and tactics in the name of anti-fascism. What these subsequently entailed in practice were matters of interpretation and compromise, as the prescriptions that the Congress had offered were far too vague to serve as any kind of clear blueprint for action. Nevertheless, it was this more permissive atmosphere that subsequently enabled at least some communists to respond more flexibly to local political opportunities.

It quickly became evident that creating "united fronts" of the working class as a prerequisite for "people's fronts" was unrealistic and even offers of limited joint action were mostly rejected. Nor were all communists enthusiasts for collaboration; compromise and negotiation did not sit easily with Bolshevik diehards and many activists were uneasy. In the case of the Chinese Communist Party (CCP) there was outright rejection when Comintern leaders encouraged the party to seek accommodation with Chiang Kai-shek's Nationalists, with whom they were engaged in a civil war. Only an attack on China by Japan in 1937 would bring them together in a fragile alliance of convenience. Years of attacks on other working-class parties by communists could also not simply be overcome overnight. Overtures to the Labour and Socialist International for cooperation were rejected, as were offers of joint action by the overwhelming majority of socialist parties. Although there were sympathetic voices within socialist ranks, there was also a deep well of distrust of communist motives based on past experience, which reflected a bitter rivalry between sibling movements that also claimed to speak for the working classes. 
For many socialists, communist anti-fascism appeared as just a tactical facade behind which lay the same old hegemonic intentions. In addition, the small size and marginal importance of the great majority of communist parties reduced even further the appeal of any kind of partnership with them. The spread of right-wing dictatorial regimes in Europe and the Americas, alongside the large areas of the globe under authoritarian colonial rule, severely limited the number of countries in which it was even possible to organize and act openly. In liberal-democratic Scandinavia, the Low Countries, Britain and Ireland, where the threat from the far right was relatively weak, there was little incentive for noncommunists to cooperate. Even in Czechoslovakia, which was the only part of Central Europe not under authoritarian rule and with a strong communist party, offers of unity and cooperation were rejected by the socialists. Consequently, unity on communist terms was therefore overwhelmingly rejected and it was only in very specific circumstances that it proved possible to create alliances.

The Popular Fronts that were formed in France, Spain and Chile during I936 and I937 were actually loose electoral alliances, in which communists mostly played minor and variable roles, rather than ones based upon united fronts of the organized working class. Their creation was driven only partly by a desire to forestall the spread of fascism, though anti-fascist rhetoric was certainly part of the ideological glue that bound them together. More important was blocking the political right, in whatever guise, from government at times of acute economic crisis and social polarization. Only in France was the role of the Communist Party (PCF) truly crucial. A large and wellorganized party, with an independent trade union federation (CGTU), the PCF was an established force on the political left. When its leader, Maurice Thorez, began to call for a Front Populaire (in one of the first uses of the term) from 1934 the groundwork for cooperation with the socialist movement was already being laid through local cooperation between trade unions and later by joint candidacies in municipal elections. While the Comintern could now endorse these actions, it was also clear that a communist-socialist election pact was incapable of defeating the coalition of the conservative-right that seemed poised to take power as the existing government faltered. It was only when the middle-class Radical Party and a number of smaller leftist parties added their weight that a Popular Front was finally agreed to fight the April i936 elections.

In contrast, the much smaller Chilean Communist Party (PCCh) and the Spanish PCE were in no position to play such pivotal roles to bring about popular fronts. Calls from the party leaders, Carlos Contreras Labarca and 
José Díaz, for united fronts and people's fronts were initially rejected or ignored, particularly by the Chilean and Spanish socialist parties. In Chile, it was the defeat of the disunited center-left parties in the March 1937 congressional elections, plus the prospects that the right would also win forthcoming presidential elections, that provided the impetus for a Popular Front. Its key creators were the radical and socialist parties, with radical-socialists, democrats and communists playing only lesser roles. The PCE was even more fortunate in finding itself as part of the Spanish Popular Front, given that it played no active part in its creation. Instead in Spain it was the socialist and left republican parties which were at the heart of negotiations in late 1935 to form an electoral alliance - or rather to re-form on new terms the electoral and government coalition that had brought the republic into being in I93I, but which had collapsed in 1933. A disastrous attempt in October 1934 to oust the resulting center-right government had ended in failure, provoking a brief workers' rising in the mining region of Asturias which had been crushed by the army and police forces. Subsequently, the PCE had erroneously tried to claim credit for this "October Revolution," gaining some credibility with the Comintern as a result. It certainly shared the same fate as all the other parties of the left in finding its leaders imprisoned or in exile and its press silenced. The calling of new elections for February 1936 then provided the impetus to form an electoral coalition to keep the right from power. Initially, the PCE was excluded from negotiations by the republicans and moderate wing of the Socialist Party (PSOE). However, for his own purposes the leader of the socialist left, Largo Caballero, insisted that the PCE be brought into the Popular Front, alongside a host of other smaller movements of the far left. Otherwise, the party would have remained isolated. This was a decision that Caballero was later to regret bitterly as it unwittingly gave the PCE a credibility that it otherwise lacked. The degree to which the PCE had no say in this process was made evident when its vehement objections to the admittance of the "Trotskyists" of the POUM (Workers' Party of Marxist Unification) were simply ignored. Consequently, the PCE appeared as a very incidental force in an unwieldy electoral bloc that ranged from moderate republicans to both orthodox and dissident communists.

This rather fragile unity was reflected by electoral platforms that were compromises designed to avoid disputes between the coalition partners and to maximize popular appeal. Keeping the right from power and containing the lurking threat of fascism reflected the only really common aims. The electoral program of the Spanish Popular Front also included promises of an amnesty for those imprisoned after the October rising. Though broadly 
"progressive" in outlook, there was little otherwise in the agreed programs of the Popular Fronts that could be identified as specifically reflecting the aims and aspirations of their communist participants. Equally, however, there was nothing in them that was particularly objectionable. More positively, there was a commitment to economic and social reform though often with little in the way of specific policies. Cultural differences also played a significant part in drawing together the participants in these Popular Fronts, and in differentiating them from their opponents. The most obvious example was in terms of the deep clerical-anticlerical divisions within Chile, France and Spain, with the Popular Fronts presenting themselves as champions of "modern" values against religious reaction. This encompassed matters far beyond just the position of the Catholic Church and included attitudes toward gender roles, education, the family and sexual relations. The acquiescence of the communists gave a strong impression that they had tacitly accepted "bourgeois" norms, prompting some criticism from within party ranks. This was reinforced by the increasing use of "national" and "patriotic" symbols by communist parties, though in ways that tried to reinterpret them in anti-fascist and revolutionary forms. This addressed deeper questions about how communists could reconcile a commitment to the creation of a universal proletarian civilization with the existence of liberal nation-states, particularly when one of the most effective charges against them had been that they were "unpatriotic." The French Popular Front, in particular, promoted the idea that it was saving the nation from forces linked to threatening outside powers - a description that could equally apply to the PCF and its links to the USSR. Not surprisingly, the French party, but also others, struggled to find a middle ground over how they related to "their" nations.

Willingness to accept these broad "anti-fascist" electoral positions might have given the impression that communists had quietly surrendered any real commitment to a separate revolutionary mission and identity. But any appearances that communist ideology had been decisively "diluted" or "toned down," as has sometimes been argued, masked a more complex reality. While the communists accepted these agreements in order to be included in Popular Fronts this did not therefore mean they had forsworn their ultimate ambitions, as was demonstrated during the electoral campaigns themselves. While they fulfilled their obligation to support all the parliamentary or presidential candidates from their respective Popular Front coalitions under the common programs, they continued to campaign separately on their own issues, including the abolition of private property and 
the creation of future Soviet-style regimes. In communist eyes tactical support for the Popular Front did not alter their long-term strategic aims nor did they cease to see themselves as essentially revolutionaries. In fact, the inclusion of communist candidates in all the electoral slates presented to voters in Spain and France in February and April-May 1936 actually enhanced their political profiles and gave them new platforms from which to espouse their ideological views. Similar opportunities were given to the Chilean communists during the presidential campaigns of 1937 and 1938. Communist activism was also crucial in strengthening the leftist character of the Popular Front and in identifying this with communism. For the PCE, in particular, this was to prove a crucial boost to the party's credibility, helping it to emerge from political marginality toward becoming an established force alongside its anarchist and socialist rivals. However, party leaders and the Comintern were acutely aware of the "danger" posed by an increasing accommodation with the bourgeois regimes they existed to overthrow and with other political movements that they were still striving to supplant. And this fear helped guide their actions during the euphoria of the so-called Popular Front springs that followed.

These electoral victories did not lead directly to governments that were representative of the Popular Front alliances that had produced them. In every case the goal of keeping the right from power was achieved, and also brought the PCE seventeen parliamentary deputies, having previously had only one, while the PCF gained seventy-two seats. The election of Aguirre Cerda to the presidency in Chile in 1938 served the same essential purpose, though rather bizarrely his victory was achieved with the last-minute endorsement of his candidacy by the Chilean Nazi Party. The question then was how far cooperation would continue subsequently in terms of forming and supporting new governments. In Spain the issue did not arise as there was never any intention to form a coalition government of the Popular Front, which to all intents and purposes ceased to exist having served its electoral purpose. Instead, the left republican parties formed a minority government, with no representation from the working-class movements including, crucially, the socialists. Similar circumstances applied in Chile in 1938 when the PCCh was denied cabinet positions in the government headed by Aguirre Cerda in which the radicals were utterly dominant, save for a few minor positions given to the socialists. In contrast, in June 1936 the PCF was directly offered ministerial posts in a coalition government by the socialist leader Léon Blum. Considerable discussion with the Comintern followed before the leaders of the PCF finally declined the offer on the 
grounds that acceptance would compromise their ideological integrity and be met with hostility by party members. Instead the new administration was formed by the socialists and radicals alone. It was clear in every case that mutual wariness between communists and noncommunists continued to run deep.

The position adopted by the Comintern was, in effect, that the popular front was fine as a defensive shield in the anti-fascist struggle but it should not to be allowed otherwise to inhibit communists' freedom of action. The ambiguous position initially proved advantageous in the face of rising social and political tensions. Freed from the constraints of government, the communists were able to become fully involved in waves of worker protests and demands for increased social welfare. The communist trade union federation in France and the communist factions within the socialist unions in Spain often played leading roles, responding in many cases to pressures from their grassroots memberships. In France, cooperation with the socialist union federation led to a general strike and factory occupations in May-June I936 that ended in agreements with employers conceding a range of improvements in wages and conditions of work. Spain also saw a steep rise in strike activity and land invasions during the spring, with communists acting alongside their more numerous anarchist and socialist counterparts. The large May Day parades mounted in the major cities of both countries publicly celebrated these achievements, demanded solidarity with the Soviet Union and exhorted further advances in the struggle against fascism. In Chile the PCCh also played a key role in urban and rural labor disputes, pressing in particular for agrarian reform. By placing pressure on the new governments, communist parties became part of a de facto left opposition in both the street and from within parliament. In Spain the PCE shared an almost identical position to Caballero's wing of the socialists, closely linked to the unions, which called for a socialist transformation of society.

A surge in communist popularity and strengthened organizations were the immediate rewards, further reinforcing the sense that the parties involved had chosen their positions wisely. All the parties gained members, most notably and dramatically in the case of the PCE whose ranks nearly quadrupled between March and July 1936. This upward trajectory, which continued into 1937, finally turned the PCE into a "party of the masses" on a scale which began to match the socialists. The profiles of those joining were also broadly similar: predominantly young, mostly male trade unionists with no previous political affiliations; this was exactly the constituency previously dominated by the left wing of the socialist movements. In Spain this marked 
the beginning of a complex process of cooperation and rivalry by which the communists were to displace Largo Caballero's section of the socialists. Communist unions or union factions, as in Spain, also flourished. This included the spread of communist unionism into the countryside for the first time, mostly among rural laborers but also with the formation of peasant leagues in Chile. Inevitably these developments impacted upon relations with other working-class movements, particularly the socialists. In Spain this was accompanied by a realignment of political organizations with novel consequences. The growing youth section of the PCE formally joined its socialist counterpart in a new body, the United Socialist Youth (JSU), whose formation in April 1936 was facilitated and approved by the Comintern. There were also unapproved negotiations between four small "Marxist" groups in Catalonia, including the Catalan section of the PCE, which finally resulted in their merger into a new party, the Unified Socialist Party of Catalonia (PSUC) in July 1936. The leaders of the PSUC sought recognition from the Comintern as a party separate from the PCE; when this was finally granted in 1939 Spain became the only country with two communist parties. In Spain, at least, it seemed that the long-sought project of a single party of the working class under communist tutelage was finally making progress.

These communist successes came at a price in terms of tensions with their anti-fascist partners and in exacerbating social and political divisions. To their electoral allies the French and Spanish communists appeared opportunistic and unreliable. This mistrust was at its deepest with their respective socialist parties, which feared that under the banner of cooperation the communists' intentions were as predatory as ever. Their growing prominence, both within and without the institutions of government and the state, also helped fuel anti-communism and the rise of the radical right. The Comintern's policy that communist parties should form armed "self-defense" organizations both reflected and contributed to a corresponding spread of violence. But this did not mean that communist leaders were blind to the risks that were being run. Parties were also warned of the dangers of provocations by the right amidst instances of sporadic violence. In France and Chile these never reached the point of a complete breakdown in order, but the fears were real. In May 1936 the Comintern, concerned at the signs of growing polarization and political violence in Spain, specifically informed the PCE leaders that they needed to avoid weakening the authority of the government, presided over by the left republican parties, to the point that it might collapse and open the door to fascism: It was to prove a prescient warning. 
The sudden outbreak of civil war in Spain produced conditions that not only led to a revival of the Popular Front but were to transform its nature and the role of the communists within it. Following the attempted military coup of I7-I8 July 1936 that sparked off the war, there was a near-collapse of state authority. In those areas that had not fallen to the insurgents and their rightwing allies, the ensuing power vacuum was filled by a patchwork of organizations that assumed local authority. At the forefront were the trade unions and the political parties of the left, particularly where they exercised armed force through militias or retained the support of local police and military forces. Within the emerging loyalist zone this decisively reinforced the importance of the working-class movements, and marked the relative eclipse of the middle-class republican parties in terms of their real influence. An immediate casualty of the war was the all-republican government placed into office after the February elections. The nature of local control varied hugely, depending upon the mix of organizations and political groups in any given village, town, or city neighborhood. Representatives formed ad hoc committees to deal with the practical problems of running their localities, replacing or displacing the previous system of government and authority in the process. The demands upon them were huge: ensuring security and defense, organizing production and work, and meeting the practical needs of the local population. While sheer necessity was a primary driver, this also represented a radical and unplanned alteration to existing social and political structures. In areas such as the city of Barcelona and the region of Aragón where they predominated, many anarchists and the dissident communists of the POUM consequently viewed this as an opportunity finally to achieve their different revolutionary goals.

Anti-fascist cooperation accordingly gained a new urgency in what quickly became a life-and-death struggle for survival and to shape the future of Spanish society. Members of the PCE and the Catalan communists in the newly formed PSUC were active participants in these developments, sometimes taking prominent roles in places like Madrid and Valencia where they had a strong presence. Likewise, members of the party militia, the Workers' and Peasants' Anti-Fascist Militia (MAOC), swelled by a rush of new volunteers, were quickly caught up in the initial confused fighting. Communists also joined local committees and were enthusiastic participants in activities such as the seizure of property from suspected nationalist supporters and other "security" measures. But how the conflict was to be conducted, particularly in terms of any reconstituted system of government, was a question that those on the republican side were immediately forced to confront in the face 
of the advancing insurgents. The problem was that, while they were united in their desire to defeat their "fascist" opponents, they were not all in agreement as to how best that was to be achieved, nor to what final end.

A return to a revised form of popular front was an obvious answer. While there was a broad consensus that cooperation was a necessity, the ensuing process of reconstituting political alliances proved problematic. As the largest political movement, allied to a strong trade union federation, it was clear that the Socialist Party would have to be at the heart of any effective coalition. However, when Largo Caballero agreed to form a new national government it took protracted negotiations before a new cabinet was announced in early September 1936. One stumbling block was whether the PCE could be persuaded to participate. Initially, the collapse of the rising in large parts of Spain, including most of the major cities, mistakenly convinced PCE leaders that the insurgency would soon implode - a message that the Comintern's advisor, Vittorio Codovilla, also passed on to Moscow. Even after it became clear that this was not the case, the Spanish communists saw no need to alter their existing political stance. Accordingly, when offered government posts the PCE rejected the offer on the understanding that this was Comintern policy. It was only after consultation with Moscow that this decision was reversed in line with the assessment by the Comintern and Soviet leadership that the grave threat posed by fascism in Spain now justified such involvement. It was similar thinking, matched by growing evidence of the extent of Axis aid for the nationalists, which also prompted the exceptional offer of Soviet military aid to the republicans - a policy that ran counter to the nonintervention promoted by the Western Allies and which was to fatally undermine Stalin's attempts to reach an accord with them.

Two communist minsters, Jesús Hernández and Vicente Uribe, subsequently joined the first truly representative Popular Front government in Spain. This new precedent was later to be followed in Chile when communists joined a similar coalition government with none of the prohibitions that had previously been placed on the French party. Along with socialists, Caballero's government also contained left republicans, Catalan nationalists and three members of the anarchist Confederación Nacional del Trabajo (CNT). Enticing anarchist ministers into the government had proved an even greater task, requiring them to compromise their deepest principles at the cost of dividing the anarchist movement in the process. To make matters even more complicated, separate coalition governments were also created in the autonomous regions of Catalonia and the Basque Country. Regional nationalists headed both of these administrations, in alliance with 
republicans, socialists and communists. In the Basque Country, the regional section of the PCE played only a minor role holding no significant ministerial positions. In contrast, in Catalonia the Catalan communists within the newly formed PSUC were a more important component of the coalition, particularly as the regional CNT refused to participate. Even so, PSUC leaders were unable to prevent, despite their vociferous objections, the inclusion of a representative, Andreu Nin, from the Trotskyist POUM. In practice, therefore, what emerged was not a single cohesive popular front but a plurality of individually negotiated popular fronts that varied in composition and with overlapping, and potentially competing, areas of authority.

Like all the other loyalist groups, the Spanish communists were forced to radically rethink their political position in the light of these new circumstances. The choices they faced were not easy, particularly in terms of their self-identification as revolutionaries and their previous reluctance to compromise too deeply with the "bourgeois" republic to whose defense they were now committed. The most obvious was the absolute commitment to the Popular Front, now radically reimagined as not just an electoral alliance but the basis for a reconstructed state. Achieving and preserving unity was of paramount importance in winning the war, and the Comintern constantly reminded the PCE and PSUC leaderships of this. But this was now taken to mean the translation of the Popular Front into every institution of authority, including the military forces. This redefined the republic itself as no longer just a "bourgeois" democracy but as an anti-fascist regime with "progressive" features which included state direction of the economy, the redistribution of landed estates, and forms of workers' control under government supervision. This led to the idea that the Spanish and Catalan communists were promoting a "democratic republic of a new type," sensitive to the concerns of more enlightened members of the middle class, but essentially dedicated to the interests of the working class and poor peasantry. This redefinition also allowed the Spanish communists to vigorously defend a switch from previously attacking the parliamentary regime to now defending it. Moreover, they also presented the war not as a civil war at all but as a war of "national liberation" against the Axis powers and their fascist allies within Spain. Although falling short of the full Bolshevik ideal, this allowed the communists to argue that they were still acting as revolutionaries - while simultaneously rejecting as "absurd" the revolutionary claims of the anarchists and POUM. This reformulation was undertaken in consultation with the Comintern and particularly with Palmiro Togliatti, its deputy leader and representative in Spain during the second half of the war, giving it wide 
importance as a further refinement of communist thinking about the Popular Front and its potential as a route toward a socialist society.

It was really only at this point that the Comintern embraced the Popular Front fully, though this did nothing to dispel the suspicion in the eyes of noncommunists that this was a subterfuge. The PCE and PSUC continually defended themselves against charges of opportunism and sectarianism made in response to their rapid rise to prominence during the early phase of the war. Indeed, by the spring of 1937 communists were found holding positions of responsibility in all the organizations and institutions created by the republic, including the army, police and security services. The numbers of party members had also grown rapidly to make the PCE a truly mass party after years of marginality and its members also played key roles within other organizations. In addition, the PCE sponsored a swathe of so-called mass organizations open to all comers and which provided a variety of health and welfare services, produced propaganda and purported to represent groups such as "anti-fascist" women and peasants. The PCE also continued to argue for the creation of a united party of the working class, meaning the fusion of the communists with the socialists - a proposal that was entirely dismissed by the socialists. It was not so surprising, therefore, that other members of the Popular Front coalition - particularly the anarchists and left socialists - found the PCE threatening and possibly duplicitous in its intentions.

The PCE presented itself as making great sacrifices in order to preserve the Popular Front, but this was balanced by an increasingly aggressive stance toward anyone perceived to threaten its unity. It was a natural corollary to the changes in communist thinking that anyone who did not fully support the Popular Front that represented "the people," and the creation of a state based upon it, was either a "fascist" or was acting in ways that consciously or unconsciously aided fascism. Communist rhetoric and actions were accordingly uncompromising toward anyone labeled a fascist, promising their destruction as enemies of "the anti-fascist people." By definition this included anyone in the nationalist camp, but it also included elements within the republican side such as "uncontrollable" anarchists who rejected a centralized war effort and, above all, the Trotskyists of the POUM. Coinciding with the turn toward the terror in the USSR, which also engulfed the Comintern, the PCE and PSUC conducted a vigorous campaign against their rivals in the POUM, arguing that they should be excluded from the Popular Front and suppressed as disguised fascists. Doing anything about this was, however, another matter. There was to be a persistent tension between what the party leadership, and the Comintern, desired and the ability to 
realize those desires within the confines of coalition politics. Despite the growing prominence of the Spanish and Catalan communists, they were never in a position to dictate government policy at any level - at least not without running the risk of fatally undermining the Popular Front by alienating other parties in it. In particular, the need to keep the bulk of the anarchists on board and to keep good relations with the socialists was always of fundamental importance. This was to lead to continued frustrations and it rather confirmed the communist fear that alliances posed a potential trap in terms of pursuing their own aims and political identity.

The wartime Popular Front in Spain never proved the stable and cohesive coalition, united in its purpose, that the communists had hoped for. Lots of different factors contributed to this, not least the tensions and rivalries between the socialists and anarchists. The underlying pressures came, however, from the failure to turn the tide of the war in favor of the republicans. By the spring of 1937 this focused in particular on Largo Caballero's leadership of the government, and specifically on his insistence on retaining the additional role of minister of war. Critics from the right of his own party, allied to the republicans and communists, gradually withdrew their support for him, demanding a greater drive toward centralizing the war effort. In May this growing political crisis was compounded by the outbreak of street fighting in Barcelona (the so-called May Days) where local tensions exploded into confrontation between forces of the regional government and local anarchists and supporters of the POUM. Although suppressed by force, this precipitated the temporary withdrawal of anarchist ministers and a cabinet coup that removed Caballero from power. The new socialist prime minister, Juan Negrín, from the right of the party, pursued a policy of centralization which included taking greater control over Catalonia and reducing the power of the trade unions. The government, strongly urged on by the communists, also banned the POUM (and ignored the murder of Andreu Nin by Soviet agents) and marginalized the anarchists. Although the same organizations remained represented in the Popular Front, and in the coalition government, this effectively signaled a realignment in which the right of the Socialist Party took power from the left and the communists and republicans shifted their allegiances accordingly. Nevertheless, despite some significant attempts to seize the military advantage, the war continued to go against the republicans. In March 1939 the government was overthrown in an internal military coup, backed by a range of supporters who had become disillusioned with the failure to end the war and who desired a negotiated peace with Franco. Strongly proclaiming their anti-communist credentials, they were rebuffed 
and the remnants of the republic collapsed. This internal rupture and decisive military defeat brought a bitter final end to the Popular Front in Spain. Summoned to Moscow and fearful of retribution, the leaders of the PCE and Comintern advisors naturally blamed everyone but themselves for its failure.

As it was, the anti-fascist alliances elsewhere already seemed to be in a state of decay. In France the Popular Front had finally dissolved in August 1938 following mounting and irreconcilable policy and political differences among its participants. The PCF had increasingly opposed the government, dominated by the more conservative Radical Party after Blum lost power in June 1937. Disagreements covered domestic labor and economic policies, the failure of France to aid the Spanish republic in the civil war, and the signing of the Munich agreement - the last of which led to a disastrous general strike called by the communist unions. Similar tensions also pulled apart the Popular Front in Chile during 1940. As a consequence, the PCCh fought the 194I congressional elections alone but, nevertheless, gained seats for the first time. However, the Soviet and Comintern leadership were not concerned for long with these failures as the signing of the Nazi-Soviet pact in August 1939 immediately made anti-fascism an embarrassment rather than a priority. Instead the Comintern urged its member parties to denounce the subsequent outbreak of war in Europe as a capitalist conflict and to oppose the war efforts of the Western democracies, sowing consternation and confusion among the ranks of communists around the world. While dramatic and shocking, this reversal marked the final abandonment of a policy of political alliances and cooperation that already seemed exhausted. The achievements of the various Popular Fronts now appeared fleeting as the international communist movement found itself once again thrown into crisis and uncertainty. With its functionaries decimated by the Soviet terror and lacking any clear role after the civil war in Spain, the Comintern itself was moribund and completely sidelined by Stalin.

From a communist perspective, the Spanish Civil War saw the popular front idea taken to its most developed form as the potential basis for a new type of the "anti-fascist" state. However, this was not really the result of any conscious strategy but largely occurred as a reaction to circumstances not previously envisioned. Indeed, it would be wrong to describe the Comintern as having adopted a popular front "strategy" as such, let alone one that led inexorably to this political outcome - this only appeared to be the case with the benefit of hindsight. Nevertheless, the more pragmatic approach adopted by the Comintern to political alliances and joint actions in the 
name of anti-fascism was important. To a great extent this reflected the communist experience of popular fronts as a whole, where a more accurate description of the changes after 1935 was later summed up by a prominent Spanish communist, Santiago Carrillo, as having introduced "firmness and strategic intelligence into the project of change of that period." ${ }^{3}$ Nor was this simply a passing phase. Instead, this more flexible attitude and the notion of the Popular Front (or something very like it) were to become enduring features of international communism and part of the established political lexicon of the left more generally - although it required the Axis attack on the USSR in June I94I to see a decisive revival. Suddenly, the demands of war and resistance to occupation placed opposition to fascism even more strongly at the forefront of Soviet and communist priorities. At this point the communist role in the war in Spain, and the idea of the Popular Front more generally, once again became a model to be applauded and applied. The forms that these were to take - from the "anti-fascist people's democracies" of postwar Eastern Europe to the ill-fated Popular Unity government of Salvador Allende in Chile during the I970s - were never exact repetitions of the experiences of the I930s. Likewise, the central unsolvable dilemma of "popular frontism" endured: how to achieve genuine cooperation for an apparently greater good while preserving the assumed purity of communist ideals.

\section{Bibliographical Essay}

The popular front period of the I930s is of such significance that all the histories of the Comintern and the international communist movement deal with it. For good recent examples see Serge Wolikow, L'Internationale Communiste (1919-1943): Le Komintern ou le rêve déchu du parti mondial de la révolution (Paris: Éditions Ouvrières, 20II); Silvio Pons, The Global Revolution. A History of International Communism, 1917-1991 (Oxford: Oxford University Press, 20I4); and Kevin McDermott and Jeremy Agnew, The Comintern: A History of International Communism from Lenin to Stalin (Basingstoke: Macmillan, I996). In many ways the best starting point for more specific research are the essays in Serge Wolikow and Annie BletonRuget (eds.), Antifascisme et nation. Les gauches européennes au temps du front populaire (Dijon: Éditions universitaires de Dijon, I998); Martin Alexander and Helen Graham (eds.), The French and Spanish Popular Fronts:

3 Santiago Carrillo, Memorias (Barcelona: Planeta, I993), I4. 
Comparative Perspectives (Cambridge: Cambridge University Press, 1989); and Helen Graham and Paul Preston (eds.), The Popular Front in Europe (Basingstoke: Macmillan, 1987). On the change in Comintern policy, E. H. Carr, The Twilight of the Comintern, 1930-1935 (Basingstoke: Macmillan, 1982) remains a useful starting point. Much light is also shed by the documents in A. Dallin and F. I. Firsov (eds.), Dimitrov and Stalin, 1934-43: Letters from the Soviet Archives (New Haven: Yale University Press, 2000), and in Ivo Banac (ed.), The Diary of Georgi Dimitrov 1933-1949, trans. Jane T. Hedges, Timothy D. Sergay and Irina Faion (New Haven: Yale University Press, 2003). On the connections between Soviet foreign policy and Comintern policy see Jonathan Haslam, "The Comintern and the Origins of the Popular Front, 1934-35," Historical Journal 22 (1979), 673-91, and Silvio Pons, Stalin and the Inevitable War, 1936-1941 (London: Frank Cass, 2002). For an overview of Chile see Paul Drake, "Chile 1930-1958," in Leslie Bethell (ed.), The Cambridge History of Latin America, vol. vIII, Latin America since 1930: Spanish South America (Cambridge: Cambridge University Press, 199I), 267-310, and Manuel Loyola and Jorge Rojas (eds.), Por un rojo amanecer. Hacia una historia de los comunistas chilenos (Santiago: Impresora Vals, 2000). Overviews of the Popular Front in France, with considerable discussion of the communist role, include: Julian Jackson, The Popular Front in France: Defending Democracy, 1934-1938 (Cambridge: Cambridge University Press, 1988); Jean-Paul Brunet, Histoire du Front populaire, 1934-1938, 2nd edn. (Paris: Presses Universitaires de France, 1998); Serge Wolikow, Le Front Populaire en France (Paris: Éditions Complexe, 1999); and Danielle Tartakowsky and Michel Margairaz (eds.), L'avenir nous appartient. Histoire du Front populaire (Paris: Larousse, 2006). On the PCF, see Stéphane Sirot, Maurice Thorez (Paris: Presses de Sciences Po, 2000), and Jacques Girault, Des communistes en France (années 1920 - années 1960) (Paris: Publications de la Sorbonne, 2002). Good overviews of the Spanish Popular Front are provided by José Luis Martín Ramos, El Frente Popular. Victoria y derrota de la democracia en España (Madrid: Pasado y Presente, 20I2), and in Eduardo González Calleja and Rocío Navarro Comas (eds.), Política, sociedad, conflicto y cultura en la España de 1936 (Granada: Editorial Comares, 20II). Communist involvement in the civil war and Popular Front is covered by Tim Rees, "The Highpoint of Comintern Influence? The Communist Party and the Civil War in Spain," in T. Rees and A. Thorpe (eds.), International Communism and the Communist International, 1919-43 (Manchester: Manchester University Press, 1998), I43-67; Fernando Hernández Sánchez, Guerra o revolución. El Partido Comunista de España en la guerra civil (Barcelona: Crítica, 20Io); 
Stanley Payne, The Spanish Civil War, the Soviet Union, and Communism (New Haven: Yale University Press, 2004); Lisa A. Kirschenbaum, International Communism and the Spanish Civil War (Cambridge: Cambridge University Press, 2015); and Frank Schauff, Der verspielte Sieg: Sowjetunion, Kommunistische Internationale und Spanischer Bürgerkrieg 1936-1939 (Frankfurt: Campus Verlag, 2005). 